\title{
Recruitment of copepod nauplii into the plankton: importance of diapause eggs and benthic processes
}

\author{
Nancy H. Marcus \\ Woods Hole Oceanographic Institution Woods Hole, Massachusetts 02543, USA
}

\begin{abstract}
During the last 10 yr it has been shown that the eggs of many zooplankters (e.g. copepods, cladocerans, tintinnids) occur in bottom sediments of coastal regions. Accumulations of these eggs on the sea-bottom may represent an important source for the recruitment of individuals into the plankton. We examined vertical distribution and viability of copepod eggs at several locations in Buzzards Bay, Massachusetts USA. Cylindrical cores were obtained by divers. In the laboratory each core was divided at $1.0 \mathrm{~cm}$ intervals to a maximum depth of $10.0 \mathrm{~cm}$. From each layer 2 subcores were taken. One was suspended in seawater and incubated for several days at $19^{\circ} \mathrm{C}$. Hatched nauplii were collected, counted, and reared for identification. Viable eggs (evidenced by appearance of nauplii) were found at all depths in the sediment. The greatest densities $\left(10^{6}\right.$ to $\left.10^{7} \mathrm{~m}^{-2}\right)$ often occurred several cm below the water-sediment interface. Egg abundance was not significantly correlated with sediment grain size. The other subcore was sonified so that the eggs of Labidocera aestiva could be removed, counted, and incubated (to determine viability). Laboratory feeding experiments indicate that diapause and subitaneous eggs of $L$. aestiva remain viable after being consumed by either Capitella sp. 1 or Streblospio benedicti which are common benthic consumers in regions where eggs occur. The relative importance and influence of physical factors (waves, tidal and wind-driven currents) and biological factors (feeding and bioturbating activities of benthic animals) on the distribution, abundance, and viability of eggs on the sea-bottom is discussed.
\end{abstract}

\section{INTRODUCTION}

During the last $10 \mathrm{yr}$ it has become increasingly apparent that the eggs of many marine planktonic copepods occur in the bottom sediments of coastal regions (reviewed by Grice and Marcus, 1981). It has been suggested that the survival of these eggs, during periods which are not suitable for the existence of stages in the water column, is critical for the perpetuation of such species. A previous study (Kasahara et al., 1975a), documented the seasonal changes in egg abundance in the uppermost $1 \mathrm{~cm}$ of the sediments. In several species the peak in egg abundance preceded the disappearance of adults (and other planktonic stages) by ca. 1 mo. Thereafter, the number decreased considerably and it was proposed that the decline reflected mortality due to predation by benthic animals

Contribution No. 5364 of the Woods Hole Oceanographic Institution

(C) Inter-Research/Printed in F. R. Germany or decay by microorganisms (Kasahara et al., 1975a; Uye, 1980) However, other evidence in the literature tends to refute this hypothesis. Diapause eggs of both Labidocera aestiva and $L$. bipinnata have a tough outer covering that resists being ruptured if poked with a needle (Uye et al., 1979; Marcus, pers. obs.). Similarly the egg of Tortanus discaudatus soon after being released from the female develops a tough protective chitonous case, which is resistant to bacterial degradation (Johnson, 1967). These facts suggest that some eggs which reside in the sediments might be resistant to digestion by predators and microbial decay processes.

In this paper I present data derived from laboratory feeding experiments, that demonstrate survival of eggs of Labidocera aestiva after passage through the gut of 2 polychaete species. I also report the existence of large quantities $\left(10^{6}\right.$ to $\left.10^{7} \mathrm{~m}^{-2}\right)$ of viable eggs between 1.0 and $10.0 \mathrm{~cm}$ depths in sediments from Buzzards Bay, Massachusetts, USA. Results suggest that the temporal decline in egg abundance reported for the uppermost 
centimeter of the sediments is due to the translocation of eggs from the sediment surface to deeper strata, and does not necessarily reflect mortality. The redistribution of eggs could be the result of resuspension due to wave action, current flow and tidal mixing, or the feeding and burrowing activities of benthic animals. Accumulations of such large numbers of viable eggs at depth in the sediments may have an important influence on the population dynamics of planktonic communities by providing a potentially large source of nauplii for recruitment.

\section{MATERIALS AND METHODS}

To evaluate the impact of predation on egg mortality we conducted several feeding experiments in the laboratory using diapause and subitaneous eggs of the calanoid copepod Labidocera aestiva. Females produce subitaneous eggs during summer and fall in the Woods Hole region, whereas diapause eggs are produced only during fall. Both egg types are ca. $112 \mu \mathrm{m}$ in diameter, with a smooth outer surface.

Eggs were obtained from Labidicera aestiva females collected in the field or reared in the laboratory. For each experiment, 300 to 700 eggs (diapause or subitaneous) were mixed with ca. $2.0 \mathrm{~g}$ of prepared sediment and seawater (filtered through a $5 \mu \mathrm{m}$ mesh bag) in a small dish. The sediment was collected from Buzzards Bay and frozen until needed. It was then thawed and sieved through a $70 \mu \mathrm{m}$ Nitex mesh screen. The material that passed through the mesh was used in the experiments to ensure that extraneous eggs and predators were not present. Two predator species were tested, Capitella sp. 1 (provided by J. Grassle) and Streblospio benedicti (provided by L. Levin). Each species is common in the areas where eggs normally occur in the bay. The test animals were kept in filtered seawater for $12 \mathrm{~h}$ prior to each experiment, and then 6 to 10 Capitella sp. 1 or 3 to $6 S$. benedicti were added to the dishes with the egg-sediment mixture. The dishes were placed at $19{ }^{\circ} \mathrm{C}$ for 12 to $24 \mathrm{~h}$, after which the contents were examined with a dissecting microscope. Fecal pellets were collected from each dish with a pipette. Many of the pellets contained eggs. For each experiment, some pellets were dissected to extract the eggs which were then placed in filtered seawater in screwcapped jars, and incubated at $19{ }^{\circ} \mathrm{C}$. Other pellets that contained eggs were left intact and placed in filtered seawater in a second set of jars. These were also incubated at $19^{\circ} \mathrm{C}$. Eggs that had not been offered to predators, and so were never ingested, were placed in a third set of jars and incubated, to serve as controls. The jars placed at $19^{\circ} \mathrm{C}$ were examined within 4 to $5 \mathrm{~d}$ and the number of eggs that hatched was recorded.
The conditions under which the eggs or pellets were incubated (i.e. $19^{\circ} \mathrm{C}$ ) after the feeding period reflected the type and prior history of the eggs used in each experiment. Subitaneous eggs will normally hatch within 2 to $3 \mathrm{~d}$ if incubated at $19^{\circ} \mathrm{C}$. Diapause eggs can be induced to hatch by chilling them at $5{ }^{\circ} \mathrm{C}$ for 2 to $4 \mathrm{wk}$, followed by warming to $19^{\circ} \mathrm{C}$. Hatching will then occur in 2 to $3 \mathrm{~d}$. For Experiments 1 and 2 subitaneous eggs were used, so the incubation temperature was $19^{\circ} \mathrm{C}$. For Experiments 3 to 6 diapause eggs had already been chilled for the required minimum period of $4 \mathrm{wk}$, so that subsequent to feeding these eggs and pellets were placed directly at $19^{\circ} \mathrm{C}$ to induce hatching.

On several occasions fecal pellets containing what appeared to be eggs of Labidocera aestiva were observed in the sediment samples (see below) collected from Buzzards Bay. These pellets were incubated at $19{ }^{\circ} \mathrm{C}$ and the number of eggs that hatched was recorded.

To evaluate the importance of translocation, I investigated the vertical distribution, abundance, and viability of eggs in the bottom sediments at several stations $(3,6,10,12$, and 14) in Buzzards Bay, MA (Fig. 1). At each station, 2 cores were carefully inserted into the sea bottom by SCUBA divers, then capped at the top and bottom, and transported upright to the surface. In the laboratory, the cores were subdivided at $1.0 \mathrm{~cm}$ intervals to a maximum depth of $10.0 \mathrm{~cm}$. Two subcores (A and $B$ ) were taken from the central region of each layer. The volume of each subcore was $1.77 \mathrm{~cm}^{3}$. Subcore A was suspended in $100.0 \mathrm{ml}$ of filtered seawater in a dish, which was then covered and placed at $19^{\circ} \mathrm{C}$ and a $20 \mathrm{~h}$ to $4 \mathrm{~h}$ light-dark cycle, for 4 to $7 \mathrm{~d}$. Every 2 to $4 \mathrm{~d}$ the contents of the dishes were examined. Nauplii were collected by decanting the seawater and filtering the material through a $70 \mu \mathrm{m}$ Nitex mesh screen. Clean. filtered seawater was added to the dishes with sedi-

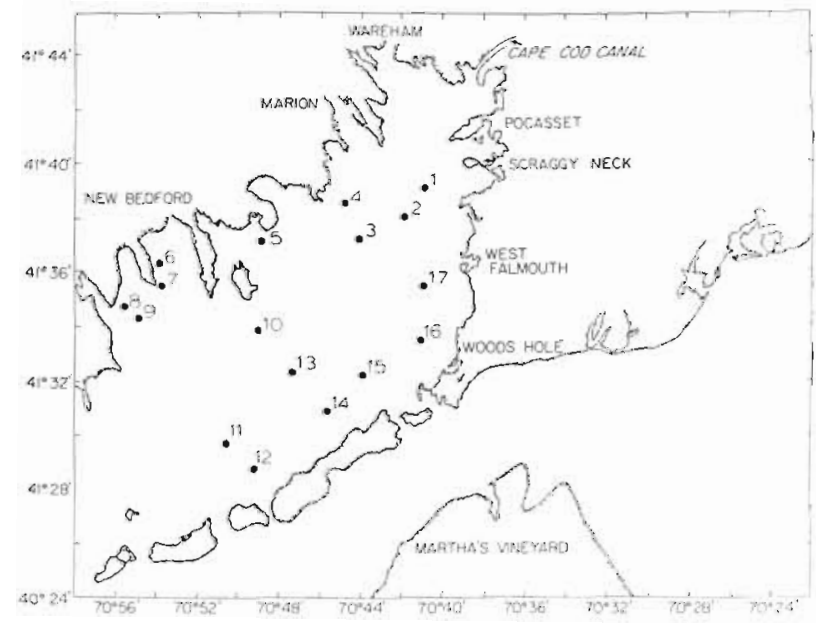

Fig. 1 Sampling sites in Buzzards Bay 
ment which were then returned to the incubator. The fraction retained on the mesh was washed into a small chamber and observed with a dissecting microscope to count the number of nauplii present. As time permitted, nauplii were reared to a recognizable stage for identification. The diet consisted of a mixture of Rhodomonas lens, Gymnodinium nelsoni, Gonyaulax polyedra, Prorocentrum micans, and Scrippsiella trochoideum.

The number of nauplii determined by this method reflects the number of viable eggs that hatch under the specific conditions imposed in the laboratory. Therefore the values do not necessarily reflect the total number of eggs present in the sediment.

By analyzing the B subcores in a variety of ways, I found that the most accurate and efficient method for determining the number of eggs in a sample involved the use of high frequency sound which Wall and Dale (1968) had shown to be effective for the extraction of dinoflagellate cysts from sediments. The sediment sample was suspended in filtered seawater in a 250.0 ml plastic beaker, which was then placed in an ultrasonic water bath for 10 to $15 \mathrm{~min}$. After sonication the material was filtered through a $70 \mu \mathrm{m}$ Nitex mesh screen and the fraction remaining on the screen was observed with a dissecting microscope. After such treatment, smooth eggs of various sizes were readily visible and could be counted. Spiny eggs however tended to be caught-up in fibrous material and were more difficult to recognize. To achieve an accurate count of their numbers was therefore more time consuming.

This protocol was followed to determine the vertical distribution and viability of eggs of Labidocera aestiva in the bottom sediments at Station 14 in Buzzards Bay. The results of the preliminary experiments on sonication indicated that egg viability was not altered by the treatment. Four collections were obtained between October 1982 and February 1983. After the eggs were extracted from the sediments, and counted, they were placed in filtered seawater in dishes and incubated at $19^{\circ} \mathrm{C}$. After 4 to $5 \mathrm{~d}$ the number of these eggs that hatched was determined. The eggs that did not hatch were chilled at $5^{\circ} \mathrm{C}$ for $4 \mathrm{wk}$, and then warmed at $19^{\circ} \mathrm{C}$. The number of additional eggs that hatched after this treatment was then recorded.

On 16 November 1982 we conducted a survey in Buzzards Bay to identify appropriate sites for further study. The 17 sites that were visited included the 5 which were previously sampled by the SCUBA divers. At each station sediment was collected with a Van Veen grab. After being hauled to the surface, a plastic vial $(4.0 \mathrm{~cm}$ diameter) was inserted into the surface of the collected material and then capped. In the laboratory the vial was kept frozen for grain size determina- tion. At the time of analysis, the upper $2.0 \mathrm{~cm}$ of sediment in each vial was removed and treated by standard methods (Folk, 1974). At 9 of the stations (1, 2, $5,6,10,11,15,16$, and 17) a second vial sample was also taken from the grab material. In the laboratory the entire upper $1.0 \mathrm{~cm}$ of sediment was suspended in filtered seawater in a dish and incubated and monitored for nauplii as described for Subcore A.

\section{RESULTS}

In the laboratory predation experiments hatching was observed for both subitaneous and diapause eggs that were dissected from fecal pellets as well as those still contained in pellets (Table 1). The proportion of diapause eggs that hatched after ingestion was comparable (all $\left.\chi^{2} .05<3.84\right)$ to the hatch of control eggs, however the hatch for ingested subitaneous eggs was significantly (both $\chi^{2}{ }_{.05}>3.84$ ) lower than controls. The pellets obtained from the field collected samples were all approximately $250 \mu \mathrm{m}$ in width and $500 \mu \mathrm{m}$ in length, and morphologically similar. They contained as many as 4 eggs. All together 15 eggs were observed and after incubation at $19^{\circ} \mathrm{C}, 60 \%$ of these hatched. However, each pellet was surrounded by a membrane which apparently prevented the escape of some nauplii. Eventually these individuals died.

Table 1. Labidocera aestiva. Percent hatch of ingested eggs dissected from or inside fecal pellets, and uningested control eggs

\begin{tabular}{|c|c|c|c|}
\hline & $\begin{array}{l}\text { Experiment no./ } \\
\text { Egg type }\end{array}$ & $\begin{array}{c}\text { Number of } \\
\text { eggs }\end{array}$ & $\begin{array}{l}\text { Hatch } \\
(\%)\end{array}$ \\
\hline \multicolumn{4}{|c|}{ Subitaneous } \\
\hline & $\begin{array}{l}\text { Streblospio benedicti } \\
\text { Eggs, dissected } \\
\text { Control }\end{array}$ & $\begin{array}{l}20 \\
50\end{array}$ & $\begin{array}{l}50 \\
80\end{array}$ \\
\hline (2) & $\begin{array}{l}\text { Capitella Sp. } 1 \\
\text { Eggs, dissected } \\
\text { Control }\end{array}$ & $\begin{array}{l}12 \\
89\end{array}$ & $\begin{array}{l}66 \\
92\end{array}$ \\
\hline \multicolumn{4}{|c|}{ Diapause, pre-chilled } \\
\hline (3) & $\begin{array}{l}\text { Streblospio benedicti } \\
\text { Eggs, dissected } \\
\text { Eggs in pellets } \\
\text { Control }\end{array}$ & $\begin{array}{l}25 \\
18 \\
94\end{array}$ & $\begin{array}{r}84 \\
100 \\
90\end{array}$ \\
\hline (4) & $\begin{array}{l}\text { Eggs, dissected } \\
\text { Control }\end{array}$ & $\begin{array}{r}24 \\
100\end{array}$ & $\begin{array}{l}87 \\
83\end{array}$ \\
\hline (5) & $\begin{array}{l}\text { Capitella sp. } 1 \\
\text { Eggs, dissected } \\
\text { Eggs in pellets } \\
\text { Control }\end{array}$ & $\begin{array}{l}25 \\
14 \\
93\end{array}$ & $\begin{array}{l}80 \\
86 \\
90\end{array}$ \\
\hline & $\begin{array}{l}\text { Eggs, dissected } \\
\text { Control }\end{array}$ & $\begin{array}{r}21 \\
100\end{array}$ & $\begin{array}{l}80 \\
83\end{array}$ \\
\hline
\end{tabular}


Table 2. Total number of nauplii hatched from each subsample, after incubation of Subcore A at $19^{\circ} \mathrm{C}$ for 7 d. Numbers in parentheses: water depth in $m_{\text {i }}$ dashes: subsample not analyzed

\begin{tabular}{|c|c|c|c|c|c|c|c|c|c|c|c|}
\hline \multirow{2}{*}{$\begin{array}{c}\text { Station and } \\
\text { collection date }\end{array}$} & \multirow{2}{*}{$\begin{array}{c}\text { Core } \\
\text { no. }\end{array}$} & \multicolumn{10}{|c|}{ Depth interval $(\mathrm{cm})$} \\
\hline & & 1 & 2 & 3 & 4 & 5 & 6 & 7 & 8 & 9 & 10 \\
\hline Station 3 & 1) & 73 & 33 & 58 & 40 & 13 & 16 & 26 & - & - & - \\
\hline $10 / 8 / 82$ & 2) & 98 & 184 & 8 & 7 & - & - & - & - & - & - \\
\hline Station 6 & 1) & 390 & 105 & 132 & 99 & 75 & 45 & 2 & 0 & 0 & 0 \\
\hline $7 / 2 / 82$ & 2) & 425 & 445 & - & - & 94 & 37 & 10 & 0 & 0 & 0 \\
\hline Station 9 & 1) & 14 & 14 & - & - & - & - & - & - & - & - \\
\hline $11 / 16 / 82$ & 2) & 14 & 29 & - & - & - & - & - & - & - & - \\
\hline Station 12 (17) & 1) & 46 & 27 & - & - & - & - & - & - & - & - \\
\hline $11 / 16 / 82$ & 2) & 81 & - & - & - & - & - & - & - & - & - \\
\hline Station 14 (16) & 1) & 60 & 50 & 28 & 24 & 21 & - & - & - & - & - \\
\hline $6 / 23 / 82$ & 2) & 63 & 135 & 158 & 111 & - & 140 & 43 & - & - & - \\
\hline $7 / 6 / 82$ & 1) & 57 & 34 & 47 & 40 & 6 & 13 & 0 & 5 & 2 & 0 \\
\hline & 2) & 23 & 20 & 102 & - & 22 & 24 & 15 & 6 & 6 & 0 \\
\hline $7 / 21 / 82$ & 1) & 29 & 21 & 11 & 161 & 252 & 194 & 90 & 10 & 48 & 30 \\
\hline & 2) & 97 & 9 & 11 & 14 & 111 & 28 & 35 & 22 & 7 & 7 \\
\hline $10 / 20 / 82$ & 1) & 94 & 175 & 51 & 232 & 68 & - & - & - & - & - \\
\hline & 2) & 217 & 307 & 506 & 178 & 73 & - & - & - & - & - \\
\hline $11 / 16 / 82$ & 1) & 124 & 400 & 184 & 319 & 43 & - & - & - & - & - \\
\hline & 2) & 62 & 519 & 201 & 269 & 146 & - & - & - & - & - \\
\hline
\end{tabular}

For the sediment samples collected by diving, viable eggs (indicated by the presence of nauplii) were found at all depths, although not in every core (Table 2). The greatest number did not necessarily occur in the uppermost centimeter of the sediments but often occurred several centimeters below the water-sediment

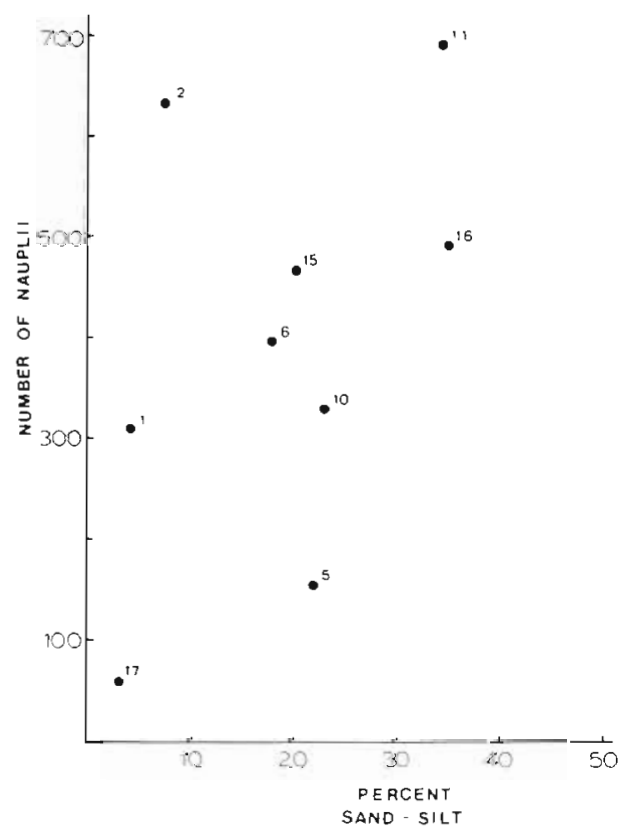

Fig. 2. Labidocera aestiva. Scatter diagram of number of nauplii hatched from sediments collected on 16 November 1982 after incubation at $19^{\circ} \mathrm{C}$ for $1 \mathrm{wk}$ vs percent of total sediment in the $31>125 \mu \mathrm{m}$ size fraction interface. The number of nauplii that hatched from the incubated sediments varied as much as an order of magnitude for comparable depth strata from different stations and sometimes between cores from the same station. Since these values reflect the laboratory conditions tested in this study, it is probable that incubations at different temperatures and for different periods of time would yield different results. Unfortunately due to time constraints not all subsamples could be analyzed By rearing nauplii that hatched from some of the subsamples, several species were positively identified, Labidocera aestiva, Centropages hamatus, Acartia hudsonica, A. tonsa, and Eurytemora americana. For the sediment samples collected with the Van Veen grab on 16 November 1983 a significant correlation between the number of nauplii hatching from incubated sediments and grain size of the sediments was not evident (Fig. 2).

The total number of Labidocera aestiva eggs extracted from the sediments collected at Station 14 varied throughout the study period ranging from 58 to 88 (Table 3). The overall mean was $73.1 \pm 8.9$ and there is no significant difference between the mean values for each collection date (tested by ANOVA, F = $0.8)$. Although a trend towards decreasing numbers for the entire $5.0 \mathrm{~cm}$ interval was not evident as time progressed, the proportion of eggs in the uppermost centimeter declined as the season progressed. However, this decrease was complemented by an increased proportion of eggs in the $2.0 \mathrm{~cm}$ layer. Little change 
Table 3. Labidocera aestiva. Proportion of total number of eggs in the B subsample from each $1.0 \mathrm{~cm}$ depth interval to $5.0 \mathrm{~cm}$ at Station 14

\begin{tabular}{|ccccccccc}
\hline \multirow{2}{*}{ Date } & $\begin{array}{c}\text { Core } \\
\text { no. }\end{array}$ & Total & \multicolumn{5}{c}{ Depth layer (cm) } \\
\cline { 1 - 5 } $10 / 20 / 82$ & 1 & 81 & .66 & 17 & 11 & .06 & 0 \\
& $2 \cdot$ & 70 & .73 & .27 & - & - & - \\
$11 / 16 / 82$ & 1 & 58 & .59 & 19 & 14 & .07 & .01 \\
& 2 & 75 & .52 & .24 & .05 & 12 & .07 \\
$12 / 22 / 82$ & 1 & 88 & .44 & .32 & .11 & .11 & .01 \\
& 2 & 72 & .50 & .33 & .07 & .08 & .02 \\
$2 / 1 / 82$ & 1 & 68 & .47 & .37 & .12 & .03 & .01 \\
& 2 & 73 & .58 & .34 & .07 & 0 & .01 \\
& $\bar{x} 73.1 \pm 8.9$ & & & &
\end{tabular}

- Only based on top $2.0 \mathrm{~cm}$. Subsample from $3 \mathrm{~cm}$ was spilled and other subsamples could not be analyzed due to lack of time

was observed below this level for the period of study. The percent hatch of eggs extracted from the sediments varied (Table 4). For the first 2 collections in October and November, the proportion of eggs that hatched after the initial incubation at $19^{\circ} \mathrm{C}$ increased with depth in the sediments. By December and February however, this trend was no longer apparent. Most eggs which did not hatch after the initial incubation at $19^{\circ} \mathrm{C}$ did so after being exposed to $5^{\circ} \mathrm{C}$ for $4 \mathrm{wk}$.

\section{DISCUSSION}

Elucidation of factors that influence the temporal and spatial patterns of marine species on both ecological and evolutionary time scales is a fundamental problem in biological oceanography. For investigators interested in determining the basis of quantitative and qualitative fluctuations in zooplankton communities, it has become increasingly evident that attention must be given not only to features of the pelagic environment, but also the benthic environment. During the last 10 yr it has been shown that the eggs or cysts of many copepods as well as other planktonic organisms (i.e. cladocerans, tintinnids, dinoflagellates) occur in the bottom sediments of coastal regions (Dale and Yentsch, 1978; Onbe, 1978a, b; Paranjape, 1980; Grice and Marcus, 1981; Anderson et al., 1982). Accumulations of these stages on the bottom may represent an important source for the recruitment of individuals into planktonic populations. To evaluate their importance it is necessary to assess the distribution, abundance, and viability of these stages in the sediments and to elucidate the factors which influence these parameters as well as the actual recruitment process of individuals back into the planktonic population.

This paper provides the first evidence that the eggs (especially diapause eggs) of a planktonic marine copepod are resistant to digestion by predators. Such resistance has been demonstrated for diapause eggs of freshwater copepods, cladocerans, and rotifers (Mellors, 1975; Gilbert and Wurdak, 1978; Hairston et al., 1983). Diapause eggs of Labidocera aestiva appear to be more resistant to digestion than subitaneous eggs as indicated by the greater mortality of subitaneous eggs after ingestion (Table 1). The capacity to survive after ingestion may be influenced by the feeding and digestive processes of the predator species. The 2 animals tested in this study do not have crushing mouthparts or claws, and thus it is possible that other more powerful predators may be capable of breaking the eggs. Moreover, if material is processed and passes through

Table 4. Labidocera aestiva. Number of eggs/subsample for each $1.0 \mathrm{~cm}$ depth interval at Station 14 . Numbers in parentheses: proportion of these eggs that hatched after initial incubation at $19^{\circ} \mathrm{C}$ for 4 to $5 \mathrm{~d}$ and after chilling at $5^{\circ} \mathrm{C}$ and then warmed to $19^{\circ} \mathrm{C}$

\begin{tabular}{|c|c|c|c|c|c|c|}
\hline \multirow[t]{2}{*}{ Date } & \multirow{2}{*}{$\begin{array}{c}\text { Core } \\
\text { no. }\end{array}$} & \multicolumn{5}{|c|}{ Depth layer $(\mathrm{cm})$} \\
\hline & & 1 & 2 & 3 & 4 & 5 \\
\hline \multirow[t]{2}{*}{$10 / 20 / 82$} & 1 & $53(.21 / .85)$ & $14(.62 / .77)$ & $9(.66 / .89)$ & $5(1.00 / 1.00)$ & 0 \\
\hline & 2 & $51(.43 / .80)$ & $19(.74 / .95)$ & - & - & - \\
\hline \multirow[t]{2}{*}{$11 / 16 / 82$} & 1 & $34(.26 / .41)$ & $11\left(.10 /^{*}\right)$ & $8(.62 / .88)$ & $4(.75 / 1.00)$ & $1(1.00 / 1.00)$ \\
\hline & 2 & $39(.23 / .92)$ & $18\left(.72 /^{\circ}\right)$ & $4(1.00 / 1.00)$ & $9(.78 / .89)$ & $5(.80 / .80)$ \\
\hline \multirow[t]{2}{*}{$12 / 22 / 82$} & 1 & $39(.80 / .90)$ & $28(.68 / .93)$ & $10(.70 / .90)$ & $10(.90 / 1.00)$ & $1(1.00 / 1.00)$ \\
\hline & 2 & $36(.94 / .94)$ & $24(.75 / .83)$ & $5(.80 / .80)$ & $6(.83 / .83)$ & $1(1.00 / 1.00)$ \\
\hline \multirow[t]{2}{*}{$2 / 1 / 83^{\cdots}$} & 1 & $32(.81)$ & $25(.92)$ & $8(.75)$ & $2(1.00)$ & $1(1.00)$ \\
\hline & 2 & $42(.95)$ & $24(1.00)$ & $5(.20)$ & 0 & $2(.50)$ \\
\hline
\end{tabular}


the gut rapidly the effect of digestive enzymes on the eggs may be minimized.

Under natural conditions in the field, diapause eggs of Labidocera aestiva sink to the sea bottom, remain viable, and overwinter in the sediments. Hatching presumably occurs in spring as water temperature rises (Marcus, 1979). Thus diapause eggs may be exposed to benthic predators and microorganisms for several months. The capacity to resist digestion and decay must be highly adaptive and help to ensure the availability of a large pool of eggs for recruitment of nauplii into the planktonic population. Although subitaneous eggs may also sink to the bottom prior to hatching, it is unlikely that they remain viable in the sediments for more than a few days. During this time, resistance to predation would certainly be an adaptive characteristic, but the lack or a hard protective coating for these eggs suggests that certain energetic and developmental constraints of trade-offs may preclude this adaptation. We are currently investigating the resistance of eggs of other species, as well as the effects of other predators to assess the widespread significance of the phenomenon.

In previous studies investigators reported on the distribution and abundance of copepod eggs in the uppermost centimeter of the sediments indicating that this layer contained the greatest numbers of eggs (Kasahara et al., 1974, 1975a; Kasahara and Uye, 1979). These investigators suggested that as the season progressed the decline in the number of eggs occurring in the top layer of the sediment reflected mortality due to predation (Kasahara et al., 1975a; Uye, 1980). Based upon our results I suggest that transport of the eggs to deeper levels in the sediment was the primary mechanism responsible for the decline observed in the uppermost centimeter, and that ingestion by predators actually serves to promote the ultimate recruitment of nauplii from eggs on the sea-bottom.

I contend that the temporal changes in the abundance of eggs of Labidocera aestiva observed for the upper $5.0 \mathrm{~cm}$ of the sediments (Tables 3 and 4) during winter indicates that the net direction of egg movement is downward. If so, then it follows that eggs occurring deeper in the sediments are older (i.e. were produced earlier in the season) than eggs occurring above them in the sediments. The hatch data (Table 4) support this hypothesis. For the first 2 mo, the proportion of eggs that hatched after the initial incubation at $19^{\circ} \mathrm{C}$ increased with depth in the sediments. This pattern reflects the diapause condition of most eggs produced by $L$. aestiva during fall in the Woods Hole region. Diapausing eggs do not hatch immediately, even if conditions are suitable, but rather must first complete a refractory period (Marcus, 1979). The duration of this phase is shortened by exposure to cold temperatures. Once it is completed, eggs will hatch if conditions are appropriate. I suggest therefore that the eggs which were isolated from the sediments and hatched after the initial incubation at $19^{\circ} \mathrm{C}$ had completed their refractory phase. Those that did not were probably produced later in the season and therefore had not yet completed their refractory phase. Eggs that did not hatch initially were still viable however, as evidenced by their subsequent hatching at $19^{\circ} \mathrm{C}$ after exposure to $5^{\circ} \mathrm{C}$ for 2 to $4 \mathrm{wk}$ in the laboratory. The pattern is not as obvious for the December and February collections since by this time most eggs have completed their refractory phase, regardless of when they were produced. Deviations from the general pattern might also reflect individual differences in the hatching response of eggs, as well as variation in the overall redistribution of the eggs.

The experiments which involved the incubation of sediments collected by divers from several sites in Buzzards Bay (Table 2) demonstrate the existence of very large numbers $\left(10^{6}\right.$ to $\left.10^{7} \mathrm{~m}^{-2}\right)$ of viable copepod eggs throughout the upper $10.0 \mathrm{~cm}$ of the sediments, with peak values often occurring below the uppermost centimeter. Similar distribution patterns have been reported for dinoflagellate cysts (Aderson et al., 1982). An important question suggested by these results is whether or not the eggs occurring in the deeper sediment layers still constitute a potential source of individuals for recruitment of nauplii into the planktonic populations. Although our data indicate that the eggs do remain viable, previous studies have reported that eggs do not hatch while buried under sediment (Kasahara et al., 1975b; Landry, 1975; Uye and Fleminger, 1976; Uye et al., 1979; Uye, 1980). If the eggs are an important source of nauplii then presumably they must be deposited at the water-sediment interface or be resuspended into the water column. To gain insight into this problem it is necessary to consider what factors influence the distribution of eggs in the sediments.

The results presented herein and available in the literature suggest the following scenario. After an egg is released into the water column it sinks and may reach the bottom, prior to hatching. Once on the bottom the egg may be resuspended into the water column and transported to a new location. If eggs accumulate in specific regions on the sea bottom then such areas may act as seed beds and provide an important source of nauplii for recruitment into the planktonic population. A similar mechanism has been proposed to account for bloom formation of dinoflagellates (Dale, 1976; Anderson et al., 1982). Dale (1976) reports the occurrence of large numbers of dinoflagellate cysts in muddy sediments and suggests that cysts and fine grain sediment particles accumulate together on the 
sea bottom due to similar sedimentary characteristics Although a significant correlation between the number of nauplii hatching from the incubated sediments and grain size was not evident in this study (Fig. 2), a correlation between the total number of eggs present and grain size may nevertheless exist. The results only represent the number of viable eggs present in the sediments that are induced to hatch by the laboratory incubation. Deviations from a value predicted on the basis of sedimentary characteristics and corresponding grain size might arise if the mortality rate of eggs differs between areas. For example, lower oxygen concentrations are more characteristic of muddy sediments than sandy areas. This difference coud lead to a greater mortality of eggs in the fine grained sediments. If such sediments were incubated in the laboratory the number of nauplii that would emerge would be lower than predicted based solely on sedimentary characteristics. Alternatively, since eggs are often sticky (own obs.) they may stick to each other or other particles and accumulate in regions on the sea bottom that reflect the sedimentary characteristics of the aggregated material, and not the individual egg.

Vertical translocation of eggs throughout the sediments may be due to turbulence and particle mixing, resulting from waves, tidal and wind driven currents, and bioturbation. The relative importance of these factors will depend on many parameters such as depth of the water column, composition and binding of the sediments, time of the year, and the presence of benthic animals. Aubrey (1979) reports large (2.0 to $30.0 \mathrm{~cm}$ ) changes in sand level off the California coast throughout the year for depths less than $10.0 \mathrm{~m}$. On the other hand, in regions such as Long Island Sound or Buzzards Bay at depths less than $10.0 \mathrm{~m}$, only the top 2.0 to $3.0 \mathrm{~cm}$ of sediments are typically affected by physical forces (Rhoads, 1974; Aller, 1980). At a depth of $15.0 \mathrm{~m}$ only the top $0.5 \mathrm{~cm}$ may be affected. Aller (1980) reports that large storms can disturb the sediments at depths greater than $15.0 \mathrm{~m}$, however the effect is reduced if the sediment surface is bound by microbial and algal films (Rhoads, 1974; Rhoads et a1., 1977. 1978). Bioturbation may decrease the stability of sediments, making them more susceptible to resuspension (Rhoads and Young, 1970; Yingst and Rhoads, 1978; Rhoads and Boyer, 1982; Grant et al., 1982) and thereby promote the translocation of eggs. In addition, the activities of benthic animals may directly affect the movement of eggs. The upper sediment layers which tend to contain the highest numbers of eggs also contain the greatest densities of potential predators (Mare, 1942; Sanders, 1960; Weiser, 1960; Rhoads, 1974). Many of these animals feed at the water-sediment interface or in the upper few centimeters of the sediment, and deposit their fecal pellets at the sediment surface. Capitella sp. 1 and Streblospio benedicti are 2 such species. Since we have shown in this study that eggs remain viable after ingestion by these predators, the deposit of their pellets at the sediment surface places the eggs in an ideal position for subsequent hatching. Eggs transported to deeper strata may be returned to the surface by "conveyer-belt" species (Rhoads and Young, 1970; Rhoads, 1974) which feed at substrate depths as great as $20.0 \mathrm{~cm}$, but deposit their pellets at the surface. Thus, the ingestion of eggs by some benthic animals may actually be critical to the maintenance of planktonic populations since by this process eggs are continually returned to the surface of the sediments where if conditions are appropriate they can hatch and give rise to a new generation.

In shallow coastal waters storm events, current flow, and bioturbation may all interact and influence the translocation and eventual hatching of eggs. Under natural conditions in the field, large bursts of hatching may be the result of widespread resuspension due to major storm events (Landry, 1978). In the absence of such large-scale physical disturbance and in deeper waters bioturbation may be of primary importance. Person-Le Ruyet (1975) reported that bursts of Acartia clausi nauplii appeared in laboratory cultures, after the addition of the benthic harpacticoid Tisbe furcata to the cultures. Presumably, the harpacticoid stirred up the sediment on the bottom of the culture dishes which promoted hatching of the $A$. clausi eggs. These results demonstrate that turbulence due to bioturbation alone is sufficient to promote hatching. Bioturbation may provide a mechanism for the continuous turnover of sediments and thereby the gradual release of individuals from the sea-bottom as suggested by Dale and Yentsch (1978) and Tyler et al. (1982) to account for the appearance of red tide in coastal areas. Since the erodibility of sediments may differ between sites due to differences in the distribution of deposit-feeders (Rhoads et al,, 1978), resuspension events should also be localized thereby providing a mechanism for the differential release of eggs from the sediments.

It is clear that numerous factors may influence the distribution, abundance, and viability of eggs on the sea bottom. Gaining insight into the temporal and spatial hatching patterns of these eggs requires an understanding of such factors and how they interact. Such information will shed light on regulation of recruitment patterns, population dynamics and fluctuations in the composition of planktonic communities.

Acknowledgements. Research supported by the National Science Foundation (grants OCE-8024440 and OCE-8314882) and Sea Grant. I would like to thank C. Fuller, I. Bosch, R. Arkowitz, and J. Scharold for assistance in laboratory and field, and J. Grassle and L. Levin for supplying the animals used in the feeding experiments. D. Anderson, T. Cowles, J. 
P. Grassle, and G. Grice provided very helpful comments on the manuscript.

\section{LITERATURE CITED}

Aller, R. (1980). Diagenetic processes near the sedimentwater interface of Long Island Sound. I. Decomposition and nutrient element geochemistry (S.N.P.). Adv. Geophys. 22: $237-350$

Anderson, D., Aubrey, D., Tyler, M. A., Wayne-Coats, D. (1982). Vertical and horizontal distributions of dinoflagellate cysts in sediments. Limnol. Oceanogr. 27: 757-765

Aubrey, D. (1979). Seasonal patterns of onshore/offshore sediment movement. J. geophys. Res. 84: 6347-6354

Dale, B. (1976). Cyst formation, sedimentation, and preservation: factors affecting dinoflagellate assemblages in recent sediments from Trondheimsfjord, Norway. Rev. Palaebot. Palynol. 22: 39-60

Dale, B., Yentsch, C. (1978). Toxicity in resting cysts of the red-tide dinoflagellate Gonyaulax excavata from deeper water coastal sediments. Science, N. Y 201: 1223-1225

Folk, R. L. (1974). Petrology of sedimentary rocks. Hamphill, Austin

Gilbert, J. J., Wurdak, E. S. (1978). Species-specific morphology of resting eggs in the rotifer Asplanchna. Trans. Am micros. Soc. 97: 330-339

Grant, W. D., Boyer, L. F., Sanford, L. P. (1982). The effects of bioturbation on the initiation of motion of intertidal sands J. mar. Res. 40: 659-677

Grice, G., Marcus, N. (1981). Dormant eggs of marine copepods. Oceanogr. mar. Biol. A. Rev. 19: 125-140

Hairston, N., Walton, W., Li, K. T (1983). The causes and consequences of sex-specific mortality in a freshwater copepod. Limnol. Oceanogr., in press

Johnson, $M$. (1967). Some observations on the hatching of Tortanus discaudatus eggs subjected to low temperatures. Limnol. Oceanogr. 12: 405-410

Kasahara, S., Onbe, T., Kamigaki, M. (1975b). Calanoid copepod eggs in sea-bottom muds. III. Effects of temperature, salinity and other factors on the hatching of resting eggs of Tortanus forcipatus. Mar. Biol. 31: 31-35

Kasahara, S., Uye, S. (1979). Calanoid copepod eggs in seabottom muds. V. Seasonal changes in hatching of subitaneous and diapause eggs of Tortanus forcipatus. Mar. Biol. 55: 63-68

Kasahara, S., Uye, S., Onbe, T. (1974). Calanoid copepod eggs in seabottom muds. Mar. Biol. 26: 167-171

Kasahara, S., Uye, S., Onbe, T. (1975a). Calanoid copepod eggs in seabottom muds. II. Seasonal cycles of abundance in the populations of several species of copepods and their eggs in the Inland Sea of Japan. Mar Biol. 31: 25-29

Landry, M. (1975). Dark inhibition of egg hatching of the marine copepod Acartia clausi Giesbr. J. exp mar. Biol. Ecol. 20: 43-47

Landry, M. (1978). Population dynamics and production of a planktonic marine copepod, Acartia clausi in a small temperate lagoon on San Juan Island, Washington. Int. Revue ges. Hydrobiol. 63: 77-119

Marcus, N. H. (1979). On the population biology and nature of diapause of Labidocera aestiva (Copepoda: Calanoida). Biol. Bull. mar biol. Lab., Woods Hole 157: 297-305

Mare, M. (1942). A study of a marine benthic community with special reference to the microorganisms. J. mar. biol. Ass. U.K. 25: 517-554

Mellors, W (1975). Selective predation of ephippial Daphnia and the resistance of ephippial eggs to digestion. Ecology 56: $974-980$

Onbe, T. (1978a). Distribution of the resting eggs of marine cladocerans in the bottom sediment of Ise Bay and Uragami Inlet, Central Japan. Bull. Jap. Soc. scient. Fish. 44: 1053

Onbe, T (1978b). The life cycle of marine cladocerans. Bull. Plank. Soc. Japan 25: 41-54

Paranjape, M. (1980). Occurrence and significance of resting cysts in a hyaline tintinnid, Helicostomella subulata (Ehre.) Jorgensen. J. exp. mar. Biol. Ecol. 48: 23-34

Person-Le Ruyet, J. (1975). Elevage de copepodes calanoides Biologie et dynamique des populations: premier resultats Annls Inst. oceanogr., Paris 51: 203-221

Rhoads, D. (1974). Organism-sediment relations on the muddy seafloor. Oceanogr. mar. Biol. A. Rev. 12: 263-300

Rhoads, D., Aller, R., Goldhaber, M. (1977). The influence of colonizing benthos on physical properties and chemical diagenesis of the estuarine seafloor. In: Coull, B. C. (ed.) Ecology of marine benthos. University of South Carolina Press, Columbia, p. 113-138

Rhoads, D., Boyer, L. (1982). The effects of marine benthos on physical properties of sediments: a successional perspective. In: McCall, P., Tevesz, M. (ed.) Animal-sediment relations. Plenum Press, New York, p. 3-52

Rhoads, D., Yingst, J., UlImann, W. J. (1978). Sea floor stability in Long Island Sound: Part 1. Temporal changes in erodibility of fine-grained sediment. In: Wiley, M. L. (ed.) Estuarine interactions. Academic Press, New York, p. 221-244

Rhoads, D. C., Young, D. K. (1970). The influence of deposit feeding organisms on sediment stability and community trophic structure. J. mar. Res. 28: 15-176

Sanders, H. (1960). Benthic studies in Buzzards Bay. III. The structure of the soft-bottom community. Limnol. Oceanogr. 5: 138-153

Tyler, M. A., Wayne-Coats, D., Anderson, D. (1982). Encystment in a dynamic environment: deposition of dinoflagellate cysts by a frontal convergence. Mar. Ecol. Prog. Ser. 7: 163-178

Uye, S. (1980). Development of neritic copepods Acartia clausi and $A$. steuri. I. Some environmental factors affecting egg development and the nature of resting eggs. Bull. Plank. Soc. Japan 27: 1-9

Uye, S., Fleminger, A. (1976). Effects of various environmental factors on egg development of several species of Acartia in Southern California. Mar. Biol. 38: 253-262

Uye, S., Kasahara, S., Onbe, T (1979). Calanoid copepod eggs in sea-bottom muds. IV Effects of some environmental factors on the hatching of resting eggs. Mar. Biol. 51: $151-156$

Wall, D. Dale, B. (1968). Modern dinoflagellate cysts and evolution of the Peridiniales. Micropaleontology 14: 265-304

Weiser, W. (1960). Benthic studies in Buzzards Bay. II. The Meiofauna. Limnol. Oceanogr. 5: 121-137

Yingst, J., Rhoads, D. (1978). Seafloor stability in Central Long Island Sound: Part II. Biological interactions and their potential importance for seafloor erodibility. In: Wiley, M. L. (ed.) Estuarine interactions. Academic Press, New York, p. 245-260 